\title{
ON A MULTIDIMENSIONAL HILBERT-TYPE INTEGRAL INEQUALITY WITH LOGARITHM FUNCTION
}

\author{
Tuo Liu, Bicheng Yang ANd LePing He
}

\begin{abstract}
By the use of the transfer formula, the methods of weight functions and technique of Real Analysis, a multidimensional Hilbert-type integral inequality with a few parameters and a best possible constant factor related to the kernel of logarithm function is given. The equivalent forms and some reverses are obtained. The operator expressions and a few particular results related to the kernels of non-homogeneous and homogeneous are considered.
\end{abstract}

Mathematics subject classification (2010): 26D15, 47A07, 37A10.

Keywords and phrases: Hilbert-type integral inequality, weight function, equivalent form, Hilbert-type integral operator, logarithm function.

\section{REFERENCES}

[1] G. H. Hardy, J. E. Littlewood, G. Pólya, Inequalities, Cambridge University Press, Cambridge, 1934.

[2] D. S. Mitrinović, J. E. PeČARIĆ, A. M. FinK, Inequalities involving functions and their integrals and derivatives, Kluwer Acaremic Publishers, Boston, 1991.

[3] B. C. YAng, Hilbert-type integral inequalities, Bentham Science Publishers Ltd., The United Arab Emirates, 2009.

[4] B. C. YAng, Discrete Hilbert-type inequalities, Bentham Science Publishers Ltd., The United Arab Emirates, 2011.

[5] B. C. YAnG, The norm of operator and Hilbert-type inequalities, Science Press, Beijin, 2009 (Chinese).

[6] B. C. YANG, Hilbert-type integral operators: norms and inequalities, (In Chapter 42 of "Nonlinear nalysis, stability, approximation, and inequalities" (P. M. Paralos et al.)), Springer, New York, 771-859 (2012).

[7] B. C. YANG, On Hilbert's integral inequality, Journal of Mathematical Analysis and Applications, 220 (1998), 778-785.

[8] Y. Hong, On multiple Hardy-Hilbert integral inequalities with some parameters, Journal of Inequalities and Applications, vol. 2006, Arcticle ID 94960, 11 pages, 2006.

[9] B. C. YAng, I. BRnetić, M. Krnić, J. E. PeČArić, Generalization of Hilbert and Hardy-Hilbert integral inequalities, Math. Ineq. and Appl., 8 (2) (2005), 259-272.

[10] M. KRnić, J. E. PeČARIĆ, Hilbert's inequalities and their reverses, Publ. Math. Debrecen, 67 (3-4) (2005), 315-331.

[11] B. C. YANG, TH. M. RASSiAs, On the way of weight coefficient and research for Hilbert-type inequalities, Math. Ineq. Appl., 6 (4) (2003), 625-658.

[12] B. C. YANG, TH. M. RASSIAS, On a Hilbert-type integral inequality in the subinterval and its operator expression, Banach J. Math. Anal., 4 (2) (2010), 100-110.

[13] L. AZAR, On some extensions of Hardy-Hilbert's inequality and Applications, Journal of Inequalities and Applications, 2009, no. 546829.

[14] B. ARpad, O. Choonghong, Best constant for certain multilinear integral operator, Journal of Inequalities and Applications, 2006, no. 28582.

[15] J. C. Kuang, L. Debnath, On Hilbert's type inequalities on the weighted Orlicz spaces, Pacific J. Appl. Math., 1 (1) (2007), 95-103. 
[16] W. Y. Zhong, The Hilbert-type integral inequality with a homogeneous kernel of Lambda-degree, Journal of Inequalities and Applications, 2008, no. 917392.

[17] W. Y. Zhong, B. C. YAng, On multiple Hardy-Hilbert's integral inequality with kernel, Journal of Inequalities and Applications, Vol. 2007, Art. ID 27962, 17 pages.

[18] B. C. YANG, M. KRnIĆ, On the norm of a mult-dimensional Hilbert-type operator, Sarajevo Journal of Mathematics, 7 (20) (2011), 223-243.

[19] M. TH. Rassias, B. C. YANG, A multidimensional half-discrete Hilbert-type inequality and the Riemann zeta function, Applied Mathematics and Computation, 225 (2013), 263-277.

[20] M. TH. RAssias, B. C. YANG, On half-discrete Hilbert's inequality, Applied Mathematics and Computation, 220 (2013), 75-93.

[21] Y. J. LI, B. HE, On inequalities of Hilbert's type, Bulletin of the Australian Mathematical Society, 76 (1) (2007), 1-13.

[22] J. C. KUANG, Introduction to real analysis, Hunan Education Press, Chansha, 1996 (Chinese).

[23] J. C. KuAng, Applied inequalities, Shangdong Science Technic Press, Jinan, 2004 (Chinese). 